\title{
LXXVII. On the carboniferous series of the United States of North America
}

\section{Richard Cowling Taylor Esq. F.G.S.}

To cite this article: Richard Cowling Taylor Esq. F.G.S. (1836) LXXVII. On the carboniferous series of the United States of North America, Philosophical Magazine Series 3, 9:56, 407-411, DOI: $10.1080 / 14786443608649033$

To link to this article: http://dx.doi.org/10.1080/14786443608649033

册 Published online: 01 Jun 2009.

Submit your article to this journal $[\pi$

Џ Article views: 2

Q View related articles $๘$ 
manner of change of this substance from its white to its yellow crystalline form. And the following is nearly what happened during its return to its former state.

When it cools, the white crystals begin to shoot, and if the microscope is adjusted upon one of the yellow hexagons, it is seen to remain quiet and undisturbed until one of the white needles, which elongate rapidly, passes near it. But when the needle passes it, even at what appears in the microscope a considerable distance, the hexagon becomes corroded on its edges, and then breaks up irregularly, and quickly dissolves.

I observed that when a needle, during its growth, happened to strike a hexagon, this seemed to check it for an instant, and then it subdivided itself into a number of ramifications or smaller needles which diverged from that point; as if the force (probably of an electrical nature) which caused the growth or formation of the needle-crystal had been deranged or subverted by the disturbing influences which it had met with.

The change from the white to the yellow form may be repeated four or five times; but when too much water has been evaporated by the heat, it ceases to occur. The white crystals then merely dissolve when heated, without the formation of the yellow ones.

Remarks.-Are the white and yellow crystals identically the same substance, assuming different forms at different degrees of temperature? Is this a case of what has been termed dimorphism? If I may venture a conjecture, I should say that the yellow crystals are a definite compound of the white crystals with water. But however this may be, it appears to me that this and other properties of the iodide of lead are worthy of being more particularly examined.*

LXXVII. On the Carboniferous Series of the United States of North America. By Richard Cowhing Taylor, Esq.s F.G.S., \&c. $†$

T HAD just completed two articles on the upper series of 1 transition rocks, and the relative positions of the depositories of bituminous and anthracitous coals in Pennsylvania, with various detailed illustrative sections, which I had pro-

- These two forms of iodide of lead are noticed in Dr. Inglis's " $E x$ tracts from his Prize Essay on Iodine ;' Lond. and Edinb. Phil. Mag, vol. viii. p. 19.-Edr.

+ Conımunicated by the Author. 
posed to myself the honour of laying before the Geological Society of London, when the interesting paper of Mr. Weaver in the Lond. and Edinb. Phil. Mag. for August 1836, reached me. I do not know how far what I have therein communicated may influence the opinions of this experienced geologist on the subject of the age of those coal deposits which I have imperfectly defined under the denomination of transition; but for similar reasons to those which have led to Mr. Weaver's communication in the Magazine, I am induced, through the same medium, to state how I have arrived at a different opinion to that which this gentleman entertains, on a very interesting portion of American geology. I should greatly hesitate in differing from an authority so deservedly eninent, and should be disposed to adhere with much less tenacity to the views which he has done me the honour to quote, but for the frank admission that he has, unfortunately, not had the advantage of seeing the district in question. However, I rejoice to perceive that the geology of this country is attracting the attention of scientific observers, who have laboured so much and so usefully in Europe, and who apply the experience acquired in one quarter of the globe to the elucidation of unsettled geological phænomena in another.

Mr. Weaver inclines to the opinion, in support of which he adduces more than one authority, that the immense series of Penncylvania rocks, amongst which are some inclosing numerous thick seams of anthracitous, passing into bituninous coals in certain places, belong altogether to the secondary carboniferous series or order. It is scarcely necessary to enter into a detailed statement of all the evidence which has occasioned a contrary decision, and which led to the classification of the eastern coal-fields and the vast succession of conglomerates and red shales and sandstones, with the grauwacké and the upper series of transition rocks.

The arrangement $I$ have adopted, for the present, may be very shortly recapitulated; commencing with the highest.

1. The (almost), horizontal carboniferous series, forming the great western bituminous coal-field of this country, whose eastern outcrop is the summit and the escarpment of the Alleghany mountain range, through the greater portion of Pennsylvania. All geological writers, I believe, concur in denominating this a secondary coal formation. This series includes the conglomerate, or pudding-stone, and grit, resembling the millstone grit, on which the series is unquestionably based.

2. The Old Red Sandstone, and red shales, many thousand feet thick. 'The dip of its numerous beds, passing 
beneath the coal formation, increases gradually in descending, until they are but a few degrees from vertical, in central Pennsylvania. Mr. Weaver is satisfied with the existence and identity of this group in York State, but not that it is identical with that which $I$ have traced from the same State and shown to pass immediately benenth the bituminous (secondary) coal-field of Pennsylvania in Tioga.

3. The Upper Transition and Grauroacké Series, conmencing at the termination of the red shales and sandstone at the base of the Alleghany mountain, and dipping at a very high angle under that mountain and the bituminous coal on its summit, the whole series being much broken and heaved up on its edges, inclining in several anticlinal and synclinal groups. In Pennsylvania this series consists of at least eight zones of (transition) limestone, in general deficient in fossils; and as many zones of sandstones and conglomerates, stretching parallel with the Alleghany. The aggregate of this upper transition system, even on the lowest computation, is of enormous thickness. It comprises four or five troughs or basins containing coal, which on the east side of the State is anthracitous, and on approaching the south-west, contains upwards of sixteen per cent. of bitumen and volatile matter.

Mr. Weaver, and one or two other writers, conceive that the whole series, from No. 1 to No. 3, inclusive, is secondary. If so, then must the grauwacké and upper transition series be absent; nor can the red sandstone under the Alleghany mountain and coal-field, be the old red sandstone, as I presumed.

I must confess that I have not seen beneath the great Alleghany coal-field a formation fully answering to the characters of the carboniferous limestone. No such rock interposes between this secondary coal-field and the red sandstone, for the occasional beds of thin gritty gray limestone, resembling the " cornstone" in the old red sandstone, cannot of course be its representative. If we select for this purpose one out of the eight zones of limestone, we might expect to find it in the first and most western; but although this slaty limestone contains some fossils in particular localities, it has no claim, par excellence, to the title of the carboniferous limestone.

In York State the limestone which is thought to resemble in geological age and character the carboniferous limestone of Europe, appears decidedly lower in the series than the group $I$ have designated as the old red sandstone, but at the same Third Series. Vol. 9. No. 56. Dec. 1836. 3 C 
time it (the limestone) reposes upon another red sandstone which Mr. Weaver considers the true old red sandstone in question. I have carefully traced these upper red sandstones from the State of New York until they sink under the great bituminous coal-field of Pennsylvania at Blossbury.

The carboniferous limestone appears on the west side of the Alleghany mountain, accompanying the coal, in Tennessee, Illinois, Kentucky, and Indiana. Its resemblance to the mountain limestone of England is, I believe, admitted by all European as well as American geologists. I am far from being certain of its presence to the eastward of the outcrop of the secondary coal-field in Pennsylvania; and $I$ doubt if in York State this is the same formation which in the west is in close approximation with, and even contains, coal seams. I do not know which of the calcareous rocks is meant by Professor Eaton, as the "limestone which supports the strata containing the Pennsylvania coal." My diagrams, which have been laboriously worked out, exhibit no limestone in Pennsylvania, between the secondary coal series and my old red sandstone group which averages a mile thick. The description, therefore, refers to the contorted and frequently highlyinclined limestones, which range alternately with the upheaved arenaceous rocks in front of the Alleghany mountain, along an area seventy miles broad. Mr. Weaver infers (p. 117.) that all the carboniferous limestone series of the north-east part of Pennsylvania supports equally the bituminons secondary coal of Clearfield, Lycoming, Tinga and Bradford, and the anthracitous deposits of Wyoming, Lehigh and Schuylkill; the red sandstone and shales being in this view continuous or identical.

Here, therefore, is the point of difference with the views I have been led to entertain. I see that both in the acknowledged secondary bituminous coal region, and in those of the anthracite districts, the carbonaceous deposits are alike based on red sandstones and red shales; but the sections distinctly show, that these are neither similar nor continuous beds, either of coal or sandstones; but are of different dates, the latter being referrible to the transition series, the former to the secondary.

On the north-east extremity of the secondary coal-field, the subjacent rocks, being much more horizontally disposed than further to the south, are more obscurely developed; but all along the eastern escarpments of the Alleghany the relative position of the entire series seems apparent enough, when traced out with ordinary caution. Mr. Weaver, however, maintains that the application of the term old red sandstone, to that rock 
immediately beneath the great coal-field, is incorrect, it being only " an alternating series lying above the great body of carboniferous limestone." This objection is obvious, if what I have termed the transition limestone at the base of this series be secondary, "carboniferous;" and if it can be proved, in the district I have imperfectly described, to "repose conformably on the extensive formation of old red sandstone."

On this head I wish to be understood, not as insisting on the infallibility of my own individual sentiments, but as desirous of apprising geologists of the grounds on which those views were founded. At the same time I am not quite prepared to admit, with Mr. Weaver, that the whole of the coal deposits in Pennsylvania, belong to one great carboniferous order, and that the fact " is fully established by Professor Eaton." (p. 131.)

A vast cleal of investigation remains yet to be entered into before these debateable points can be adjusted. There is good prospect of some of them being shortly elucidated by the geological surveys simultaneously going on in the States of New York, Pennsylvania, Maryland and Virginia.

Philadelphia, Sept. 23, 1836.

LXXVIII. Physiological Remarks on certain Muscles of the Upper Extremity, especially on the Pectoralis Major. By F. O. Wand, Esq., King's College, London.*

[With a Plate.]

THERE is a remarkable fold in the tendon of the pectoralis major, which, though described by all anatomists, has never yet, I believe, been explained. The muscle consists of two portions, one smaller and upper, arising from the clavicle, and passing downward and outward; the other larger and lower, arising from the sternum and ribs, and having a general direction upward and outward. The fibres of the muscle thus converging towards each other, terminate in a flat tendon several inches wide, which is attached to the upper part of the humerus.

Instead, however, of having the usual simple insertion represented in Plate IV. fig. I, the lower part of this tendon is folded up, behind the upper portion, so that the margin B appears above the margin $A$, as represented in fig. 2 .

As it is an axiom in physiology that every arrangement is to be accounted for, this peculiar twist has given rise to several speculations. Some suppose it designed merely to diminish the extent of the insertion. Others believe it to have

* Read before the Royal Society June16th, 1836 : and now communicalcd by the Author. 